\title{
Inducing institutional change through projects? : Three models of projectified governance
}

\section{Munck af Rosenschold, Johan}

2019-07-04

Munck af Rosenschold, J 2019 , ' Inducing institutional change through projects? Three models of projectified governance ' , Journal of Environmental Policy \& Planning , vol. 21 , no. 4 , pp. 333-344 . https://doi.org/10.1080/1523908X.2019.1606702

http://hdl.handle.net/10138/306504

https://doi.org/10.1080/1523908X.2019.1606702

acceptedVersion

Downloaded from Helda, University of Helsinki institutional repository.

This is an electronic reprint of the original article.

This reprint may differ from the original in pagination and typographic detail.

Please cite the original version. 
This is an Accepted Manuscript of an article published by Taylor \& Francis in Journal of

Environmental Policy and Planning on 14 April $2019^{1}$, available online:

https://www.tandfonline.com/doi/10.1080/1523908X.2019.1606702

\title{
Inducing Institutional Change through Projects? Three Models of Projectified Governance
}

\author{
Johan Munck af Rosenschöld \\ University of Helsinki, Finland \\ Email: johan.munckafrosenschold@helsinki.fi
}

\begin{abstract}
The study of short-term projects to implement policy has lately gained ground among scholars of environmental governance and public administration. The increasing reliance on and prevalence of projects, or 'projectification', has spurred critical debates on the ability of projects to contribute to longterm goals, including sustainability, as well as institutional change. Yet, the literature on projectification lacks specificity in terms of how projects are understood, how the relationship between projects and permanent organizations looks like, and how projects can influence institutional orders. The aim of this paper is to systematize the literature in order to uncover the process of transforming project outputs into institutional change. Three models of projectified governance - mechanistic, organic, and adaptive - is presented, providing a conceptual apparatus that advances the study of projects in environmental policy and governance. The paper argues that the adaptive model, with its reliance on multi-scalar networks for the coordination of project activities and knowledge, shows most promise in achieving institutional change to address complex environmental problems.
\end{abstract}

Keywords: governance; project; projectification; institutional change; environment

\footnotetext{
${ }^{1}$ To cite: Munck af Rosenschöld, J. (2019) Inducing institutional change through projects? Three models of projectified governance. Journal of Environmental Policy and Planning, 21(4), 333-344.
} 


\section{Introduction}

Many of the pressing problems in environmental governance are complex and ill-defined, which questions the usability of preexisting decision-making templates. To address these 'wicked problems' (Brown, Harris, \& Russell, 2010; Rittel \& Webber, 1973), we need governance systems that are capable of absorbing new knowledge and crafting innovative solutions (Folke, Hahn, Olsson, \& Norberg, 2005). Responding to climate change and biodiversity loss, for example, requires making structural changes to laws, norms, and social practices based on incomplete, and constantly evolving, knowledge. Additionally, to avoid the worst anticipated effects, these institutional changes need to occur rapidly (van der Leeuw, Wiek, Harlow, \& Buizer, 2012). The tendency of institutions to resist change, however, slows down this process and presents significant challenges for addressing these complex challenges sufficiently (Munck af Rosenschöld, Rozema, \& Frye-Levine, 2014). Confronting institutional rigidity, or inertia, by fostering attempts to modify existing institutions thus becomes a central priority for environmental governance. Yet, there is a clear need for a better understanding of the dynamics of institutional change in environmental governance (Beunen \& Patterson, 2016).

Projects present an interesting case for institutional change. A project can be defined as an organizational form bounded by time and resources, and populated by a project team performing assigned tasks for achieving change (Lundin \& Söderholm, 1995). Projects are proposedly better equipped to manage the complexities, unpredictabilities, and rapid changes inherent in 'late modern' society (Andersson, 2009) and create more innovative solutions compared to permanent organizations, such as bureaucracies (Sahlin-Andersson \& Söderholm, 2002; Wolf, 2011). Studying projects to gain a better understanding of institutional change in the context of environmental governance shows promise.

The popularity of utilizing projects to organize work has led to what scholars are calling projectification, or 'an increasing reliance on temporary organisations, typically projects, in order to enhance action strategic effort' (Godenhjelm, Lundin, \& Sjöblom, 2015, p. 328) and a growth of project-infused discourse and techniques in society more broadly (Fred, 2018; Packendorff \& Lindgren, 2014). Projects have long been a staple format for organizing work in the private sector and have therefore been the primary focus of project management research (see e.g. Lundin et al., 2015). For nearly a decade ago, the Journal of Environmental Policy and 
Planning published a special issue devoted to exploring the role of projects and administrative short-termism in environmental governance (vol. 11, no. 3, 2009). Since then, projectification of the public sector has attracted an increasing amount of interest. Implementing policy through short-term projects remains a salient feature of public administration in developed countries, especially within the European Union (EU) (Büttner \& Leopold, 2016; Godenhjelm et al., 2015; Sjöblom, 2009). For example, in Finland alone, between 2007 and 2013 some 18,000 projects were initiated as part of the Cohesion Policy. Studying projects and projectification in the public sector is in other words not merely a conceptual exercise, but has clear scholarly and political significance.

In this paper, I explore the relationship between projectification, or projectified governance as I will call it, and institutional change in the context of environmental policy. The aim of the paper is to systematize the literature on projectified governance in order to uncover the processes of institutional change. Thus far, institutional change has been discussed in the literature in a variety of ways based on often ill-communicated assumptions about what a project is, how the relationship between projects and permanent organizations looks like, and how institutional change is supposed to occur in projectified governance arrangements. The contribution of the paper is that it addresses this lack of clarity by developing three models mechanistic, organic, and adaptive projectified governance - that reveal the often-conflicting understandings of the process of institutional change. I argue that recognizing these distinct processes is crucial if we want to gain a more fine-grained understanding of how projects can instigate institutional change.

The paper is structured as follows. I begin by discussing the importance and relevance of studying projectification and argue that adopting the concept of 'projectified governance' helps us to unpack the broader institutional and organizational environment in which projects are situated. By relying on institutional theory, I then develop a project-focused approach to complement existing debates on institutional change. Next, I present three models of projectified governance to portray different processes of institutional change and demonstrate their relevance by using examples from the existing literature. Finally, I discuss the implications of the models for the debate on projectified governance by contrasting them to different types of environmental problems. 


\section{The Foundations of Projectified Governance and Institutional Change}

Projectification mirrors different developments in policy and administrative practices. Godenhjelm et al. (2015) explain the growth of projectification in EU public policy by "push" and "pull" factors (see Godenhjelm et al. 2015 for a thorough discussion). Projectification was partly "pushed" by the economic downturn in the early 1990s and the subsequent calls for more flexible economic restructuring. Relatedly, administrative reforms in the 1980s associated with New Public Management demanded efficiency in policymaking and new non-bureaucratic ways of organizing work in the public sector. Later, New Public Governance spurred an interest in informal and temporary instruments (often borrowed from the private sector), including cross-sectoral partnerships and networks, supposedly allowing for experimentation and innovation in public administration. Another push factor is the EU Structural Funds that are ultimately implemented in individual projects through numerous programs. The pervasiveness of these projects and the adoption of an administrative infrastructure to manage these projects has formalized project-driven work in the EU across its member states (Fred, 2018). The pull factors include the growing political significance of sustainable development since the 1990s, where partnerships and projects are seen as apt for capacity-building and coordinating actions across sectors. Additionally, successful examples of projects in other sectors as well as migration of individuals to the public sector from other sectors has diffused project management ideals and practices to public administration. Thus, the increasing reliance on projects is strongly related to the developments in policy and administrative practice mentioned above. Nevertheless, projectification also presents a novel perspective, as it redirects our attention to the temporal dimension of these broader developments - more attention needs to be paid to the ways in which we coordinate work in temporary organizations and its implications for achieving public policy goals.

The projectification literature is linked to multiple topical debates in environmental policy and governance (see also Munck af Rosenschöld \& Wolf, 2017). Projectification is linked to the burgeoning literature on experiments in environmental governance (e.g. Turnheim, Kivimaa, \& Berkhout, 2018; van der Heijden, 2015) as they both focus on small-scale interventions and see these as distinct from ordinary activities in permanent organizations. The major difference between the two literatures lies in their emphasis on projects as an organizational form - not all projects are experiments, but most policy-driven experiments are organized as projects (see Turnheim et al., 2018). Projectification is also relevant for governance literatures broadly 
focusing on horizontal and vertical coordination across administrative departments, inclusion of stakeholders in decision-making, and questions of scale, including adaptive governance (e.g. Folke et al., 2005), joined-up government (e.g. Pollitt, 2003), multilevel governance (e.g. Bulkeley \& Betsill, 2005), and collaborative governance (e.g. Bodin, 2017). Taken together, projectification presents an interesting case. In relation to the aforementioned literatures, it can be seen as a cross-cutting theme that highlights the temporary nature of many governance arrangements and, more broadly, directs our attention to the often overlooked concept of time in environmental governance (Munck af Rosenschöld \& Wolf, 2017). Projectification presents a distinct focus on contemporary environmental governance by taking the role of temporally limited projects seriously in studying social action.

\section{From Projectification toward Projectified Governance}

Most studies conceptualize projectification as a process or development toward a higher number of projects as well as greater social, cultural, and political importance of projects. This development has been identified through a number of empirical studies focusing on Europe and, to a lesser extent, North America (e.g. Munck af Rosenschöld \& Wolf, 2017) and Australia (Allan, 2012). It is important to recognize the fluidity of projectification; the development toward project-based work in the public sector has not been a linear or uniform progression across localities and regions. At the same time, as argued above, projects already have material implications for the implementation of policy and shape the organizational environments in which they are conducted (Fred, 2018). Building on the existing literature on projectification, and to emphasize the importance of projects in contemporary governance, I advance the (yet undefined) concept of 'projectified governance' (see Marsden, Sjöblom, Andersson, \& Skerratt, 2012; Munck af Rosenschöld \& Wolf, 2017; Sjöblom \& Andersson, 2016). I define projectified governance as:

An arrangement constituted by organizations and individuals across sectors involved in temporary project-driven activities for the purpose of pursuing selected goals as well as the formal and informal institutions that guide these activities.

The rationale for the usage of projectified governance is twofold. First, it emphasizes the salience of projects in contemporary governance. It is both from an organizational and discursive point of view a 'substance', not only a process, accompanied by bureaucratic 
infrastructure, rules, norms, expectations, and political significance. It shifts the attention away from single projects toward studying the implications of an increasing reliance on projects in governance. Second, this conception also takes seriously the relationship between projects and the permanent organizations, such as public agencies and public project funders as well as the institutional environment of projectified governance (see Andersson, Sjöblom, Marsden, \& Skerratt, 2012; Jensen, Johansson, \& Löfström, 2017). This third point begs the question: if projects are bound by their institutional environments, how does this relationship look like and, in turn, how can projects influence institutions? In the next section, I will lay down the foundations for answering this question.

\section{Inducing Institutional Change through Projects}

Numerous studies have shown how projects are situated in broader institutional contexts that influence the functioning of the project (see e.g. Biesenthal, Clegg, Mahalingam, \& Sankaran, 2018; Engwall, 2003; Grabher, 2002). The argument is that by failing to take into account the institutional dimension, we fail to grasp a critical dimension of projects. Institutions have regulative, normative, and cognitive dimensions and are comprised of a set of relatively stable and commonly accepted rules, values, and schemas that guide actors' behavior (Scott, 2008). Institutions can be either formal, such as codified rules and laws, or informal, including norms, routines, and social practices. In a projectified context, institutions can refer to the rules or norms that enable and constrain project activities, such as funding requirements and taken-forgranted routines pertaining to managing projects. More broadly, they can also refer to framings of environmental problems as well as solutions and practices (see Beunen \& Patterson, 2016), unrelated to the immediate management of projects.

While stable, institutions do change. Institutional change can be treated as either continuous or discontinuous (Mahoney \& Thelen, 2010). Continuous change is often conceptualized as incremental change, where the process is slower, more predictable, and linear. For example, projects may produce knowledge that is more or less in line with current understandings and do not question the broader institutional setting. Over time, however, the totality of these projects can give rise to institutional change. Discontinuous change involves a transformation, or punctuation of the equilibrium, that questions the deeper structures that inform rules, norms, and how things are perceived and occur in distinct 'windows of opportunity' (Baumgartner \& Jones, 1993). Some projects, often called 'institutional projects' (Tukiainen \& Granqvist, 
2016), are purposely created to influence the institutional order, and involve key powerful actors and stakeholders that are able to alter the status-quo. These types of projects can achieve significant changes to the institutional order in a relatively shorter time span. As projectified governance is concerned with governance arrangements often built on a multitude of short-term projects (rather than a handful of high-profile institutional projects), the accumulating effect of project knowledge across time is crucial. We can therefore expect that institutional change is largely incremental, potentially followed by moments of discontinuous change.

Institutional change can also be categorized as either exogenous or endogenous. Exogenous change results from changes in the broader environment, including the political, economic, and social dynamics, which open up new opportunities for alternative trajectories (see Mahoney \& Thelen, 2010), such as economic depressions transforming entire sectors in society. Endogenous change, in turn, is a result of actions occurring within a governance arrangement, where actors shape and re-shape the institutional order. In institutional theory, endogenous change is often discussed with reference to 'institutional work' which refers to the actions that actors employ to create, maintain, and change institutional structures while at the same time being influenced by institutions (Lawrence \& Suddaby, 2006). The literature has focused on a wide variety of purposive and non-purposive actions (Beunen \& Patterson, 2016) as well as strategies that actors employ to shape existing institutions or create new ones (for an overview, see Lawrence, Leca, \& Zilber, 2013).

Conceptualizing projects as arenas for institutional work has recently received some interest. As Lundin et al. (2015, p. 197) put it, '[i]nstitutional entrepreneurship or work, we argue, is by and large a project business'. A distinction can be made between studies that focus on the capacity of individual projects and the capacity of multiple projects for inducing endogenous change (Tukiainen \& Granqvist, 2016). In a projectified setting, the focus lies on the interplay between multiple projects, on the one hand, and between multiple projects and permanent organizations, on the other. Here, institutional work is more concerned with the interaction between multiple actors, rather than the actions of individual change agents (see Beunen \& Patterson, 2016). The key interest is in other words the processes occurring on the meso or governance level of analysis.

The temporariness of projects has important implications for the study of institutional change. Knowledge generated in one particular project needs to be transferred to another project or a 
permanent organization to be acted on, and ultimately, induce institutional change (Godenhjelm et al. 2015). Learning from project-generated knowledge is a necessary step in the broader process of achieving institutional change, as knowledge needs to be adapted to, or 'translated', to the novel context in which it is enacted (Manning \& von Hagen, 2010). Exploring the means by which knowledge generated in projects is learned by other organizations thus becomes a key issue in studying institutional change (see Haunschild \& Chandler, 2008). In the context of projectified governance, I suggest that:

Institutional change is an outcome of learning from numerous project outputs, either planned or unexpected, giving rise to a revision of a set of rules, norms, cognitive frames, or social practices in one or multiple settings.

It is worth noting that not all exercises of learning from project outputs lead to institutional change - some projects generate little or no additional knowledge that would advance altering existing rules or social practices. Other times, projects may produce valuable knowledge, but learning from them is not prioritized. Additionally, although this definition of institutional change is applicable to all projectified governance arrangements, the process of transforming project outputs into institutional change remains unclear. In the next section, I will explore this process more in detail.

\section{Three Models of Projectified Governance and Institutional Change}

Based on the existing literature on projectified governance, I develop three governance models that help us categorizing the different orientations and assumptions that projects embody as well as to uncover the processes of institutional change. Drawing on the work by Burns and Stalker (1961), Morgan (1997), and Scott and Davis (2007), I call these models 'mechanistic', 'organic', and 'adaptive projectified governance'. Specifically, they focus on 1) how projects are understood, 2) the link between projects and permanent organizations, and 3) how projects are supposed to change institutions. The choice of foci is derived from central concerns emerging in the existing literature. It is also worth noting that the idea is not to compartmentalize individual studies or researchers into particular models, but to highlight the different dimension of projectified governance using illustrating examples. 


\section{Mechanistic Projectified Governance}

The mechanistic model of projectified governance is based on the view that organizations have specific motives, and that 'activities and interactions of participants are coordinated to achieve specified goals' (Scott \& Davis, 2007, p. 28). Projects work toward predetermined goals set out in the project plan and are seen to have the appropriate tools to monitor the progress of projects (Godenhjelm et al., 2015). Similarly, project participants have clearly defined roles and their responsibilities are commonly understood.

In the mechanistic model, there is a clear, formalized structure by which projects operate. Projects have a strong link to broader political strategies, such as regional development strategies and agri-environmental programs, managed by permanent organizations, including funding bodies and public agencies (see Sjöblom \& Andersson, 2016). The role of strategies is important, as they set out the main priorities to which projects are supposed to contribute. This means that 'projects are not only task- and goal-oriented, but also (perhaps even primarily) politically and strategically oriented' (Fred \& Hall, 2017, p. 189). The aims and emphases in the strategy correspond to the rationalist notion that problems are 'solvable' through coordinated efforts, utilizing highly developed project management tools and guidelines (Andersson, 2009). The permanent organizations play a significant role in projectified governance, as they are responsible for managing the overall arrangement and overseeing projects to which they have provided funding (Hodge \& Adams, 2016).

The strong link between projects and permanent organizations is crucial for institutional change. Change is believed to be a result of a vertical transmission of knowledge from the temporary project to the permanent organization funding the project, where this knowledge is presumed to be sustained once the project finishes. As a result, project outputs are expected to influence the permanent organization and the rules and norms of political decision-making 'higher up' in the projectified governance decision-making structure (Godenhjelm et al., 2015). However, if a project's outputs are too deviant from what is expected or if they question the dominant institutional order of the permanent organization, there is a great risk that generated project results 'remain isolated and will, like other foreign bodies, be rejected and become “islands in the stream"' (Jensen et al., 2013, p. 135). Rather, projects 'exploit' (Brady \& Davies, 2004; see also Duit \& Galaz, 2008) currently available knowledge, bounded by existing strategies. The role of projects in institutional change is thus to materialize the priorities and 
objectives of political strategies, which consequently can result in broader institutional change. Change is however likely to be incremental, as projects do not question the fundamental structures of the status quo.

The mechanistic model can be identified in a number of EU programs (Büttner \& Leopold, 2016), but also in agri-environmental policy in the United States (US). Munck af Rosenschöld and Wolf (2017) studied the recently initiated Regional Conservation Partnership Program, governed by the US Department of Agriculture. The program funds projects that implement a series of agricultural conservation practices on private lands. While the program emphasizes innovation and bottom-up activities on paper, the strong tradition of bureaucratic top-down steering limits the scope of projects by defining the eligible project practices a priori. The projects are thus bound by the limits set out by the permanent organization. From this perspective, institutional change is limited to implementing tried-and-tested practices in new geographical locations. This can lead to new activities being institutionalized in specific areas, and best practices from projects can be made available to permanent organizations, which, consequently, can alter rules for which practices are funded in the future.

Taken together, this suggests that political strategies play a significant role in directing project activities. However, solely looking at the formal mechanisms of capturing results from projects paints an unnecessarily one-sided picture of the reality of project-based activities and their ability to induce institutional change. In the next section, I present a distinctively different perspective, which helps us extending our understanding of projects and institutional change.

\section{Organic Projectified Governance}

The organic model of projectified governance is based on the idea that organizations are similar to organisms inhabiting natural systems. This means that the formal goals and tasks of organizations, and the notion that organizations actually perform these tasks, is deemphasized for the benefit of embracing the sociality of organizations (Scott \& Davis, 2007). In other words, there is, more often than not, a discrepancy between what the project is supposed to do and what the project, eventually, achieves. In addition, 'what' the project wants to achieve is contested among project participants, who construct their role in the project differently and may have diverging interests concerning the project (Godenhjelm, Munck af Rosenschöld, Kuokkanen, Andersson, \& Sjöblom, 2012). Contrary to the mechanistic model, it has been 
argued that 'an unclear project goal is an intrinsic element of project management' (Engwall, 2002, p. 262).

The ambiguity of project goals does not only relate to the dynamics of producing outputs. The expectations of projects may differ significantly among project participants and representatives from permanent organizations, which makes coordination of project activities highly challenging (Andersson, 2009). In organic projectified governance, the link between permanent organizations and projects is weak and based on minimal requirements regarding funding and broader contours of the project. Broader political strategies exist, but the strategies themselves are less specified and vague in terms of how expectations are supposed to be met by the projects. Thus, in contrast to the mechanistic model, the focus is on the actions of projects themselves, rather than on the ability of projects to implement pre-determined objectives imposed by the permanent organization.

The organic model builds on the criticism toward the rationalistic ideals of vertical knowledge transfer of project-generated knowledge. Many studies question the capacity of the permanent organizations to learn from and utilize project results, pointing to lack of resources and knowledge on behalf of the permanent organization (Jensen et al., 2017; Marsden et al., 2012; Munck af Rosenschöld \& Löyhkö, 2015; Sjöblom, Löfgren, \& Godenhjelm, 2013). In his study of projects as part of EU's Cohesion Policy, Vento (2017) argues that there is a mismatch between the formal evaluation tools, focusing on technical and economic performance, and the less easily measurable projects results of increased knowledge, innovation, and long-term outcomes. This has spurred discussions on alternative ways of conceptualizing project outcomes and impact. From an organic perspective, decentralizing the management of projects to various localities and contexts is at the core of projectified governance, as these constitute the arena where action is performed and its effect are largely felt. This gives projects more leeway to experiment and 'explore' new knowledge (Johansson, Löfström, \& Ohlsson, 2007; see also Duit \& Galaz, 2008).

Compared to the mechanistic model, the main goal of projects is not to integrate or 'recouple' results to the permanent organization, but to appreciate the capacity of the projects themselves to generate change. Andersson (2009, p. 199) suggests that one way to do this is 'to abandon the external requirement that projects must be innovative and instead simply let the innovative potential of project work in general play freely'. The bottom-up character of project-based work 
can have real and material effects on the environment in which the project takes place (Andersson et al., 2012), including changes to practices and cognitive frames. Here, institutional change is an outcome of a horizontal process of accumulating knowledge across local projects. Importantly, in addition to influencing the context in which the projects operate, projects can also influence the actors involved in them (see Normann, 2015) - project knowledge becomes 'embodied' in participating actors and can be enacted and translated in a new context and project. In their report on the long-term outcomes of European Social Fund projects implemented in Sweden, Sävenstrand, Svensson, Holmström, Forssell and Fred (2012) stress the importance of an active project manager to ensure that knowledge is made use of across projects. During this process, new configurations of knowledge and ideas may emerge, which can form the basis for institutional changes, both intentional and non-intentional, in both expected and unexpected contexts.

As an example of the organic model, Andersson (2009) comments on the Great Outdoors Colorado Program that provides opportunities for a wide range of actors to form partnerships to address various environmental problems. Interestingly, the content of the program is determined by the project applicants and their interests, making it sensitive to local needs and priorities. The program also provides multiple grants for one project, which can be seen to strengthen the role of projects in projectified governance. This stands in contrast to the majority of the cases that have been studied in the literature, and serves as an interesting counter-example to the mechanistic model. The organic model can also be distinguished in the earlier stages of the EU LEADER rural development program. Being a 'laboratory' (Ray, 2000) for developing new innovative ideas among local publics, companies, and local authorities, the program funds small-scale projects with significant local discretion as to which types of projects are favored. Later on, increasing bureaucratic control of the program has partly diminished its 'anarchic element' (Ray, 2000, p. 165), but the local capacity to decide on project funding persists.

Exploring new knowledge across projects with diverging interests and scope serve as the basis for the organic model. In this line of reasoning, the implementation of project knowledge in the permanent organization that funded the project is deemphasized for the benefit of seeing institutional change as a result of local projects influencing their immediate local institutions, and, over time, potentially beyond. Due to the weak link between projects and permanent organizations, projects need to find alternative routes for putting project knowledge in motion and not rely on public authorities to act on project knowledge and induce broader institutional 
change. This in turn can generate problems of coordination, as there is a risk that knowledge becomes fragmented without a designated body actively managing project activities (Sjöblom, 2009). In the third model of projectified governance, I contrast these points with the role of networks in shaping relationships and the process of institutional change.

\section{Adaptive Projectified Governance}

Many scholars have emphasized the need for considering social networks and how different relationships are structured when studying projects (e.g. Engwall, 2003; Grabher, 2004; Sydow, Schüssler, \& Müller-Seitz, 2016). Networks have proven important also in the study of public sector projects (Godenhjelm et al., 2015; Jensen et al., 2013; Kuokkanen, 2013; Sjöblom \& Andersson, 2016) and environmental governance more broadly (e.g. Bodin, 2017; Wolf, 2011). Focusing on cross-scale integration, the project is seen as 'embedded' (Manning, 2010) in project networks spanning across sectors and levels (DeFillippi \& Sydow, 2016). While the projects themselves remain important, they are conceptualized in relation to broader networks.

The adaptive features stems from the relationship between projects and permanent organization mediated by networks. Networks including actors from different sectors and on different levels play an important part in many forms of adaptive governance, thus providing an alternative to centralized and decentralized modes of governance (for an overview, see Folke et al., 2005). As projects are primarily parts of larger networks, the key question becomes how to govern these networks while retaining their core traits of autonomy (Jensen et al., 2013). Metagovernance, involving a 'combination of hands-off tools such as institutional design and network framing and hands-on tools such as process management and direct participation' (Sørensen \& Torfing, 2011, p. 861), is the primary mode of managing projects. Political strategies managed by permanent organizations are, in other words, tools for steering, but not exhaustively defining the objectives and processes of projectified governance (see also Hodge \& Adams, 2016).

Whereas the organic model stresses the horizontal relationship between local projects as the main avenue of institutional change, the adaptive model focuses on the role of multi-level networks. In other words, institutional change can be seen as an interplay between horizontal and vertical processes. Once a project is terminated, the explorative knowledge produced in the project may (or may not) become contained within the broader network of which the project is 
part of. The network itself consists of actors from various sectors in society, including actors from permanent organizations (see Sørensen \& Torfing, 2011). Bearing in mind the embeddedness of projects (and project knowledge), the capacity to induce institutional change is determined by the ability of social networks to exploit project outputs and create new trajectories (see also Duit \& Galaz, 2008). Grabher (2004) notes that networks with recurring interactions between a fixed set of actors generally leads to more 'cumulative' forms of knowledge production, whereas networks that rearrange interactions tend to promote more discontinuous forms of learning. Networks generally have both cumulative and discontinuous traits, which suggests that projects are both exploitative and explorative in adaptive projectified governance. The process of horizontal diffusion is similar to the one in the organic model, but the main differences lie in the role of networks spanning across sectors and organizations in capturing, retaining, and acting on project knowledge, and in the monitoring and steering of self-organizing networks by permanent organizations by metagovernance.

Adaptive projectified governance can be illustrated by a couple of empirical examples. In their study of 275 innovation projects funded by the European Regional Development Fund in Finland, Godenhjelm and Johanson (2018) explore the innovative potential of projects and their relationship to networks. They cast doubt on the ability of public project funders to detect links between projects that would sustain project knowledge across projects and emphasize that the networks in which project participants operate play a prime role in ensuring that the new knowledge projects produce is put into motion. They also stress the importance of enabling public sector actors to participate in project networks, especially if permanent organizations are supposed to make use of the knowledge that the projects produce. Larsson and Waldenström (2012) arrive at a similar conclusion in their study of the LEADER program in Sweden. Local networks consisting of businesses, local associations, local citizens, and local funding bodies have the ability to retain the knowledge produced in individual LEADER projects and serve as the arena for capacity building across projects. Based on LEADER projects in Hungary, Megyesi (2012) shows that project networks that are able to foster bonds among local actors and, further, to permanent organizations induce more activity and flexibility. This has arguably important implications for sharing project knowledge across scales.

These examples show that projects and networks are closely linked, and that that networks constitute important venues of coordinating project activities. Instead of focusing on the relationship between projects and permanent organization (mechanistic model) or between 
projects themselves (organic model), the adaptive model shows that institutional change is an outcome from continuous dialogue between projects and networks. Networks operate as repositories of accumulated project knowledge and as arenas for acting on that knowledge in projectified arrangements, which serves as the basis for inducing institutional change.

\section{Concluding Discussion}

The literature on projectified governance in the public sector has flourished during the last decade or so. In this paper, I have highlighted the many dimension of organizing work in projects, which have important implications for environmental governance. As a starting point, I noted that confronting institutional inertia by fostering attempts to modify existing institutions is a central priority for environmental governance. The goal of this paper was to systematize the literature on projectified governance in order to uncover the processes of institutional change induced by projects. This was done by developing three models of projectified governance - mechanistic, organic, and adaptive - that uncover these often ill-defined processes. Recognizing these processes and their differences is critical in order to gain a better understanding of projects and institutional change. They embrace different conceptions of the role of projects and permanent organizations as well as of the 'manageability' of projectified governance, which guide the study of projects and institutional change (see Table 1 for an overview).

\section{[Table 1 near here]}

In contemporary environmental governance, discussions on 'tame' and 'wicked' problems (Brown et al., 2010; Rittel \& Webber, 1973) has led to critical assessments of the appropriateness of conventional hierarchical and linear planning in dealing with many sustainability challenges. To this end, projects present an important case. The mechanistic model is well suited for simple or tame problems that are well defined and where the solution is known. The model is particularly apt in diffusing tried-and-tested technologies to locations where little adaptation is required. Providing extensive leeway in project formulation and implementation is counterproductive, as the 'recipe' already exists and flexibility may cause projects going astray from the predetermined path. Unsuspectedly, the mechanistic model is suited for many engineering projects, such as strengthening dikes to protect against flooding or installing energy-saving technologies. The prospects of institutional change are limited to 
incremental amendments institutions in an effort to optimize project outcomes. The mechanistic model has received a fair share of criticism, not least from the perspective of tackling more intricate problems (e.g. Allan, 2012). To address these, alternative ways of organizing projects need to be adopted.

The organic model is arguably better equipped to take on 'complicated' problems. These problems 'contain subsets of simple problems but are not merely reducible to them' (Glouberman \& Zimmerman, 2002, p. 1), which requires cooperation and coordination across sectors and forms of expertise. The organic model emphasizes the agency of localities and nongovernmental actors in formulating project plans and in executing them. The strength of the model is that it allows localities to translate and adapt the project according their setting, and it is useful in situations where the problem is deeply rooted in local contexts. The major drawback of the organic model is that project activities become impossible to coordinate on the supralocal level, as they are comparably less confined by broader political strategies managed by permanent organizations. For multi-scalar problems that stretch across localities and beyond, this is troublesome, as these problems require continuous institutional adaptation across governance levels in light of new knowledge.

The adaptive model mitigates much of these challenges of scale and shows most promise in dealing with non-linear 'complex' multi-level environmental problems with numerous interdependencies (Glouberman \& Zimmerman, 2002), perhaps best exemplified by climate change. The reliance on cross-sectoral networks ensures continuous feedback and flow between individual projects and broader networks, making it more open to exploration and exploitation of project activities and knowledge across multiple scales (see also Duit \& Galaz, 2008). At the same time, it emphasizes that projects need not only give rise to institutional change through formal means via bureaucracies but can exert influence in various ways. Through involvement of other local and regional actors, the knowledge produced in projects travel diagonally across project actors, sectors, and scales, which can give rise to changes in multiple settings. Studying more carefully the processes of institutional change empirically would require longitudinal or historical methodologies, which would provide a more comprehensive account of how knowledge created in projects becomes/became embedded in various social contexts and networks and how it influences/influenced them. These networks need to be studied critically, and focusing on how the network is composed and whose interests are being favored will be 
necessary (Wolf, 2011). This is admittedly no easy task, but a necessary one if we want to advance a fuller understanding of projectified governance and institutional change.

\section{Acknowledgements}

I thank the anonymous reviewers and the editor for constructive feedback on the paper. The paper also benefited greatly from comments and suggestions by Kjell Andersson, Sebastian Godenhjelm, Eva Heiskanen, Christian Jensen, Stefan Sjöblom, and Steven Wolf.

\section{References}

Allan, C. (2012). Rethinking the "project": Bridging the polarized discourses in IWRM. Journal of Environmental Policy \& Planning, 14(3), 231-241.

Andersson, K. (2009). Orchestrating regional development through projects: The "innovation paradox" in rural Finland. Journal of Environmental Policy and Planning, 11(3), 187-201.

Andersson, K., Sjöblom, S., Marsden, T., \& Skerratt, S. (2012). Conclusion: Progressing from governance challenges to approaching "must hit" spatial policy targets. In S. Sjöblom, K. Andersson, T. Marsden, \& S. Skerratt (Eds.), Sustainability and short-term policies: improving governance in spatial policy interventions (pp. 301-319). Farnham: Ashgate.

Baumgartner, F. R., \& Jones, B. D. (1993). Agendas and instability in American politics. Chicago: The University of Chicago Press.

Beunen, R., \& Patterson, J. J. (2016). Analysing institutional change in environmental governance: exploring the concept of "institutional work." Journal of Environmental Planning and Management. Advance online publication. doi:10.1080/09640568.2016.1257423

Biesenthal, C., Clegg, S., Mahalingam, A., \& Sankaran, S. (2018). Applying institutional theories to managing megaprojects. International Journal of Project Management, 36(1), $43-54$.

Bodin, Ö. (2017). Collaborative environmental governance: Achieving collective action in social-ecological systems. Science, 357(6352).

Brady, T., \& Davies, A. (2004). Building project capabilities: From exploratory to exploitative 
Learning. Organization Studies, 25(9), 1601-1621.

Brown, V. A., Harris, J. A., \& Russell, J. Y. (Eds.). (2010). Tackling wicked problems through the transdisciplinary imagination. London: Earthscan.

Bulkeley, H., \& Betsill, M. (2005). Rethinking sustainable cities: Multilevel governance and the 'urban' politics of climate change. Environmental Politics, 14(1), 42-63.

Burns, T., \& Stalker, G. M. (1961). The management of innovation. London: Tavistock.

Büttner, S. M., \& Leopold, L. M. (2016). A “new spirit” of public policy? The project world of EU funding. European Journal of Cultural and Political Sociology, 3(1), 41-71.

DeFillippi, R., \& Sydow, J. (2016). Project networks: Governance choices and paradoxical tensions. Project Management Journal, 47(5), 1-12.

Duit, A., \& Galaz, V. (2008). Governance and complexity - Emerging issues for governance theory. Governance, 21(3), 311-335.

Engwall, M. (2002). The futile dream of the perfect goal. In K. Sahlin-Andersson \& A. Söderholm (Eds.), Beyond project managment. New perspectives on the temporary permanent dilemma (pp. 261-277). Malmö: Liber.

Engwall, M. (2003). No project is an island: linking projects to history and context. Research Policy, 32(5), 789-808.

Folke, C., Hahn, T., Olsson, P., \& Norberg, J. (2005). Adaptive governance of social-ecological systems. Annual Review of Environment and Resources, 30(1), 441-473.

Fred, M. (2018). Projectification - The trojan horse of local government (Doctoral dissertation). Lund University \& Malmö University: Lund \& Malmö.

Fred, M., \& Hall, P. (2017). A projectified public administration: How projects in Swedish local governance become instruments for political and managerial concerns. Statsvetenskaplig Tidskrift, 119(1), 185-205.

Glouberman, S., \& Zimmerman, B. (2002) Complicated and complex systems: What would successful reform of Medicare look like? Commission on the future of health care in Canada. Discussion paper 8.

Godenhjelm, S., \& Johanson, J.-E. (2018). The effect of stakeholder inclusion on public sector project innovation. International Review of Administrative Sciences, 84(1), 42-62. 
Godenhjelm, S., Lundin, R. A., \& Sjöblom, S. (2015). Projectification in the public sector - the case of the European Union. International Journal of Managing Projects in Business, 8(2), 324-348.

Godenhjelm, S., Munck af Rosenschöld, J., Kuokkanen, K., Andersson, K., \& Sjöblom, S. (2012). The democratic implications of project organisations - a case study of Leaderprojects in Finland. In S. Sjöblom, K. Andersson, T. Marsden, \& S. Skerratt (Eds.), Sustainability and short-term policies: improving governance in spatial policy interventions (pp. 55-80). Farnham: Ashgate.

Grabher, G. (2002). Cool projects, boring institutions: Temporary collaboration in social context. Regional Studies, 36(3), 205-214.

Grabher, G. (2004). Temporary architectures of learning: Knowledge governance in project ecologies. Organization Studies, 25(9), 1491-1514.

Haunschild, P., \& Chandler, D. (2008) Institutional-level learning: Learning as a source of institutional change. In R. Greenwood, C. Oliver, K. Sahlin, \& R. Suddaby (Eds.), The Sage Handbook of Organizational Institutionalism (pp. 624-649). Thousand Oaks: Sage.

Hodge, I., \& Adams, W. (2016). Short-term projects versus adaptive governance: Conflicting demands in the management of ecological restoration. Land, 5(4), 39.

Jensen, C., Johansson, S., \& Löfström, M. (2013). The project organization as a policy tool in implementing welfare reforms in the public sector. International Journal of Health Planning and Management, 28(1), 122-137.

Jensen, C., Johansson, S., \& Löfström, M. (2017). Policy implementation in the era of accelerating projectification: Synthesizing Matland's conflict-ambiguity model and research on temporary organizations. Public Policy and Administration. Advance online publication. doi:10.1177/0952076717702957

Johansson, S., Löfström, M., \& Ohlsson, Ö. (2007). Separation or integration? A dilemma when organizing development projects. International Journal of Project Management, 25(5), $457-464$.

Kuokkanen, K. (2013). Assessing the democratic qualities of programmes and projects: A case from Finnish urban policy. Scandinavian Journal of Public Administration, 17(2), $127-$ 146. 
Larsson, L., \& Waldenström, C. (2012). Leader as a means for strengthening rural development capacity: From project output to the embedding of outcomes. In S. Sjöblom, K. Andersson, T. Marsden, \& S. Skerratt (Eds.), Sustainability and short-term policies: improving governance in spatial policy interventions (pp. 17-34). Farnham: Ashgate.

Lawrence, T. B., Leca, B., \& Zilber, T. B. (2013). Institutional work: Current research, new directions and overlooked issues. Organization Studies, 34(8), 1023-1033.

Lawrence, T. B., \& Suddaby, R. (2006). Institutions and institutional work. In S. R. Clegg, C. Hardy, T. B. Lawrence, \& W. R. Nord (Eds.), Handbook of organization studies (pp. 215254). London: SAGE.

Lundin, R. A., Arvidsson, N., Brady, T., Ekstedt, E., Midler, C., \& Sydow, J. (2015). Managing and working in project society: Institutional challenges of temporary organizations. Cambridge: Cambridge University Press.

Lundin, R. A., \& Söderholm, A. (1995). A theory of the temporary organization. Scandinavian Journal of Management, 11(4), 437-455.

Mahoney, J., \& Thelen, K. (2010). A theory of gradual institutional change. In J. Mahoney \& K. Thelen (Eds.), Explaining institutional change: Ambiguity, agency, and power (pp. 137). New York: Cambridge University Press.

Manning, S. (2010). The strategic formation of project networks: A relational practice perspective. Human Relations, 63(4), 551-573.

Manning, S., \& von Hagen, O. (2010) Linking Local Experiments to Global Standards: How Project Networks Promote Global Institution-Building. Scandinavian Journal of Management, 26(4), 398-416.

Marsden, T., Sjöblom, S., Andersson, K., \& Skerratt, S. (2012). Introduction: Exploring shorttermism and sustainability: Temporal mechanisms in spatial policies. In S. Sjöblom, K. Andersson, T. Marsden, \& S. Skerratt (Eds.), Sustainability and short-term policies: improving governance in spatial policy interventions (pp. 1-14). Farnham: Ashgate.

Megyesi, B. (2012). Institutions and networks in rural development: Two case studies from Hungary. In S. Sjöblom, K. Andersson, T. Marsden, \& S. Skerratt (Eds.), Sustainability and short-term policies: improving governance in spatial policy interventions (pp. 217243). Farnham: Ashgate. 
Morgan, G. (1997). Images of organization. Thousand Oaks: SAGE.

Munck af Rosenschöld, J., \& Löyhkö, J. (2015). LEADER and local democracy: A comparison between Finland and the United Kingdom. In L. Granberg, K. Andersson, \& I. Kovách (Eds.), Evaluating the European approach to rural development: Grass-roots experiences of the LEADER programme (pp. 13-31). Farnham: Ashgate.

Munck af Rosenschöld, J., Rozema, J. G., \& Frye-Levine, L. A. (2014). Institutional inertia and climate change: A review of the new institutionalist literature. Wiley Interdisciplinary Reviews: Climate Change, 5(5), 639-648.

Munck af Rosenschöld, J., \& Wolf, S. A. (2017). Toward projectified environmental governance? Environment and Planning A, 49(2), 273-292.

Normann, H. E. (2015). The role of politics in sustainable transitions: The rise and decline of offshore wind in Norway. Environmental Innovation and Societal Transitions, 15, 180193.

Packendorff, J., \& Lindgren, M. (2014). Projectification and its consequences: Narrow and broad conceptualisations. South African Journal of Economic and Management Sciences, 17(17), 7-21.

Pollitt, C. (2003). Joined-up Government: a Survey. Political Studies Review, 1(1), 34-49.

Ray, C. (2000). Editorial. The EU LEADER programme: Rural development laboratory. Sociologia Ruralis, 40(2), 163-171.

Rittel, H. W. J., \& Webber, M. M. (1973). Dilemmas in a general theory of planning. Policy Sciences, 4(2), 155-169.

Sahlin-Andersson, K., \& Söderholm, A. (2002). The Scandinavian school of project studies. In K. Sahlin-Andersson \& A. Söderholm (Eds.), Beyond project managment. New perspectives on the temporary - permanent dilemma (pp. 11-24). Malmö: Liber.

Scott, W. R. (2008). Institutions and organizations. Thousand Oaks: SAGE.

Scott, W. R., \& Davis, G. F. (2007). Organizations and organizing: Rational, natural, and open System Perspectives. New Jersey: Pearson.

Sjöblom, S. (2009). Administrative short-termism - A non-issue in environmental and regional governance. Journal of Environmental Policy \& Planning, 11(3), 165-168. 
Sjöblom, S., \& Andersson, K. (2016). The prospects for bridging spatial and institutional divides between regions: Rural-urban relationships in a projectified governance context. In K. Andersson, S. Sjöblom, L. Granberg, P. Ehrström, \& T. Marsden (Eds.), Metropolitan ruralities (Vol. 23, pp. 215-240). Bingley: Emerald Group Publishing Limited.

Sjöblom, S., Andersson, K., Marsden, T., \& Skerratt, S. (Eds.). (2012). Sustainability and shortterm policies: Improving governance in spatial policy interventions. Farnham: Ashgate.

Sjöblom, S., Löfgren, K., \& Godenhjelm, S. (2013). Projectified politics - Temporary organisations in a public context. Scandinavian Journal of Public Administration, 17(2), $3-11$.

Sydow, J., Schüssler, E., \& Müller-Seitz, G. (2016). Managing inter-organizational relations: Debates and cases. London: Palgrave.

Sävenstrand, A., Svensson, L., Holmström, P., Forssell, R., \& Fred, M. (2012). Pärlbandsprojekt: Projekt som verktyg $i$ en långsiktig utvecklingsstrategi [String of projects: Projects as tools in a long-term development strategy] (Spel-report no. 5/2012). Örebro: APeL Forskning och Utveckling.

Sørensen, E., \& Torfing, J. (2011). Enhancing collaborative innovation in the public sector. Administration \& Society, 43(8), 842-868.

Tukiainen, S., \& Granqvist, N. (2016). Temporary organizing and institutional change. Organization Studies, 37(12), 1819-1840.

Turnheim, B., Kivimaa, P., \& Berkhout, F. (2018). Experiments and Beyond: An Emerging Agenda for Climate Governance Innovation. In B. Turnheim, P. Kivimaa, \& F. Berkhout (Eds.), Innovating Climate Governance: Moving Beyond Experiments (pp. 216-241). Cambridge: Cambridge University Press.

van der Heijden, J. (2015). What "works" in environmental policy-design? Lessons from experiments in the Australian and Dutch building sectors. Journal of Environmental Policy \& Planning, 17(1), 44-64.

van der Leeuw, S., Wiek, A., Harlow, J., \& Buizer, J. (2012). How much time do we have? Urgency and rhetoric in sustainability science. Sustainability Science, 7(S1), 115-120.

Vento, I. (2017). The evaluation of innovations: How to evaluate the transformative value of 
the Cohesion Policy for managing purposes. Scandinavian Journal of Public Administration, 21(2), 3-22.

Wolf, S. A. (2011). Network governance as adaptive institutional response: The case of multifunctional forested landscapes. Journal of Natural Resources Policy Research, 3(3), $223-235$. 
Table 1. Three models of projectified governance.

\begin{tabular}{|c|c|c|c|}
\hline & $\begin{array}{l}\text { Mechanistic } \\
\text { projectified } \\
\text { governance }\end{array}$ & $\begin{array}{l}\text { Organic } \\
\text { projectified } \\
\text { governance }\end{array}$ & $\begin{array}{l}\text { Adaptive } \\
\text { projectified } \\
\text { governance }\end{array}$ \\
\hline Problem type & Simple & Complicated & Complex \\
\hline $\begin{array}{l}\text { Focal relationship of } \\
\text { interest }\end{array}$ & $\begin{array}{l}\text { Permanent } \\
\text { organization- } \\
\text { projects }\end{array}$ & Project-project & Projects-networks \\
\hline $\begin{array}{l}\text { Primary form of } \\
\text { learning }\end{array}$ & Exploitation & Exploration & $\begin{array}{l}\text { Exploitation of } \\
\text { exploratory } \\
\text { knowledge }\end{array}$ \\
\hline $\begin{array}{l}\text { Process of } \\
\text { institutional change }\end{array}$ & $\begin{array}{l}\text { Vertical transfer of } \\
\text { project knowledge to } \\
\text { higher levels of } \\
\text { decision-making }\end{array}$ & $\begin{array}{l}\text { Horizontal transfer } \\
\text { of project knowledge } \\
\text { to new areas and } \\
\text { contexts }\end{array}$ & $\begin{array}{l}\text { Horizontal transfer } \\
\text { of project knowledge } \\
\text { with vertical } \\
\text { monitoring of } \\
\text { project activities }\end{array}$ \\
\hline Promises & $\begin{array}{l}\text { Efficiency through } \\
\text { coordination; plan- } \\
\text { ability }\end{array}$ & $\begin{array}{l}\text { Flexibility through } \\
\text { local adaptation; } \\
\text { social robustness }\end{array}$ & $\begin{array}{l}\text { Flexibility and } \\
\text { coordination }\end{array}$ \\
\hline Challenges & Rigidity & Hard to control & $\begin{array}{l}\text { Balancing between } \\
\text { exploitation and } \\
\text { exploration }\end{array}$ \\
\hline
\end{tabular}

